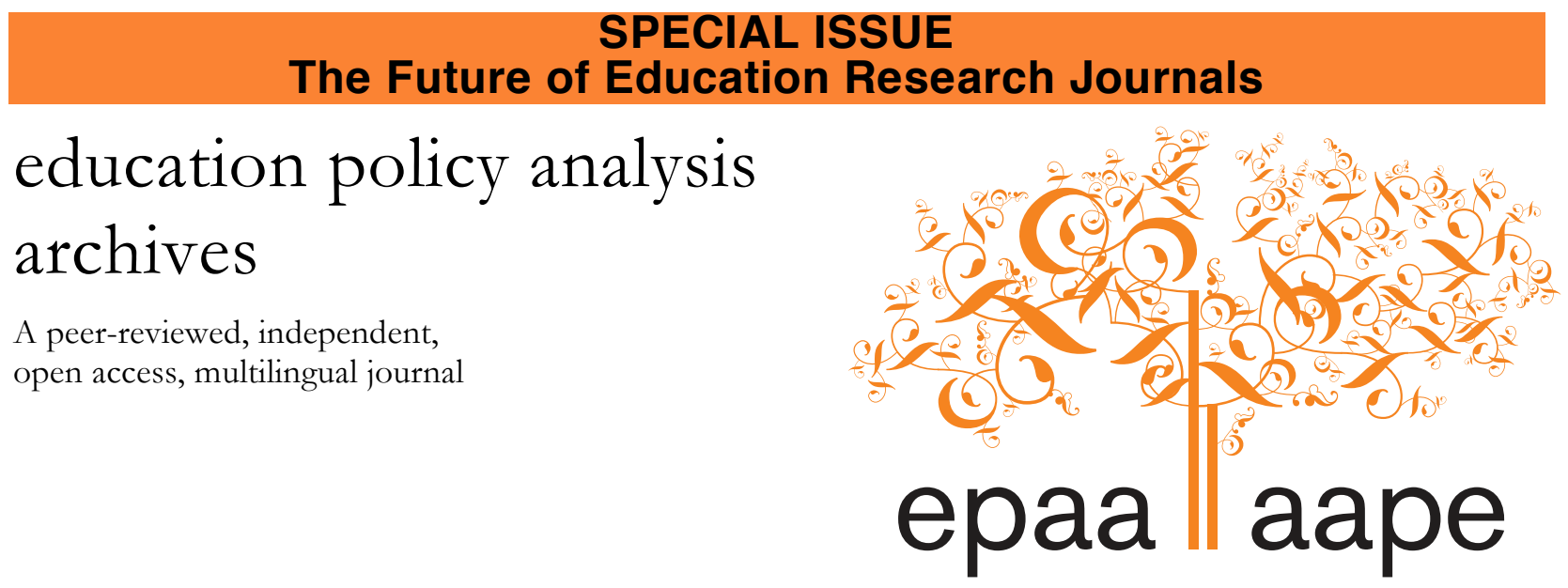

Arizona State University

Volume 22 Number $31 \quad$ May $5^{\text {th }}, 2014$

ISSN 1068-2341

\title{
The Ranking Regime and the Production of Knowledge: Implications for Academia
}

\author{
Leslie D. Gonzales \\ Clemson University \\ \& \\ Anne-Marie Núñez. \\ University of Texas at San Antonio \\ USA
}

Citation: Gonzales, L.D., \& Núñez, A.-M. (2014). The Ranking Regime and the Production of Knowledge: Implications for Academia. Education Policy Analysis Arcbives, 22 (31). http://dx.doi.org/10.14507/epaa.v22n31.2014 This article is part of EPAA/AAPE's Special Issue on The Future of Education Research Journals, Guest Edited by Dr. David Post.

\begin{abstract}
In this integrated review of literature, we address a powerful movement among interrelated organizations that we call the "ranking regime." We argue that the ostensive purpose of this regime is to identify "world class" universities, and thus to organize post-secondary education into a competitive transnational market. Although extant research has addressed how rankings are reshaping the field of higher education, there is little work that addresses the influence of rankings on the evaluation of faculty work and the production of knowledge. Thus, we review existing studies that have focused on the intersection of this ranking regime, faculty work, and faculty evaluation in order to assess the implications of the ranking regime for the production of knowledge within academia and for faculty evaluation. We argue that the ranking regime affects the production and evaluation of knowledge by promoting individualism, standardization, commodification, and homogenization. We offer policy and practice implications as well as directions for future research.

Journal website: http://epaa.asu.edu/ojs/ Facebook: /EPAAA

Manuscript received: 9/15/2013

Twitter:@epaa_aape

Revisions received: $1 / 31 / 2014$

Accepted: 3/1/2014
\end{abstract}


Keywords: rankings; evaluation; accountability; faculty roles and work; scholarship

\section{El Régimen de Clasificación y la Producción de Conocimiento: Implicaciones para la Universidad.}

Resumen: En esta revisión integrada de la literatura, analizamos un movimiento potente de organizaciones interrelacionadas que llamamos "Régimen Clasificatorio".

Argumentamos que el propósito ostensible de este régimen es la identificación de las universidades de "clase mundial", y por lo tanto organizar la enseñanza post-secundaria en un mercado transnacional competitivo. Aunque la investigación existente ha abordado cómo los rankings están remodelando el campo de la educación superior, hay poco trabajo que se ocupa de la influencia de las clasificaciones en la evaluación de la labor docente y la producción de conocimiento. De este modo, se revisan los estudios existentes que se han centrado en la intersección de este régimen de clasificación, el trabajo de los docentes universitarios, y las universidades con el fin de evaluar las consecuencias del régimen de clasificación para la producción de conocimiento en el mundo académico y de evaluación del trabajo de los docentes universitarios. Nosotros sostenemos que el régimen de clasificación afecta a la producción y la evaluación de los conocimientos, promoviendo el individualismo, la normalización, la mercantilización y homogeneización. Ofrecemos sugerencias de políticas e implicaciones prácticas, así como direcciones para investigaciones futuras

Palabras clave: clasificación; evaluación; rendición de cuentas; roles de profesores y condiciones de trabajo.

Regime de Classificação e produção de conhecimento: implicações para a Universidade Resumo: Nesta revisão integral da literatura, analisamos um poderoso movimento de organizações inter-relacionadas que chamamos de "Esquema de Classificação". Argumenta-se que o propósito ostensivo do regime é a identificação das universidades de "classe mundial" e, portanto, organizar o ensino pós-secundário em um mercado transnacional competitivo. Embora a pesquisa existente abordou como os rankings estão remodelando o domínio do ensino superior há pouco trabalho que aborda a influência dos rankings na avaliação do ensino e da produção de conhecimento. Assim estudos existentes têm-se centrado sobre a intersecção desse esquema de classificação, o trabalho de acadêmicos e universidades, a fim de avaliar as consequências do sistema de classificação para a produção de conhecimento. Argumenta-se que o esquema de classificação que afeta a produção e avaliação de conhecimento, promovendo o individualismo, a normalização, a mercantilização e homogeneização. Oferecemos sugestões de políticas e implicações práticas e orientações para futuras pesquisas

Palavras-chave: classificação; avaliação; prestação de contas; rol dos professores e condições de trabalho.

\section{Introduction}

In this integrative review of literature, we address a powerful movement among interrelated, evaluative organizations that we refer to as the "ranking regime." We argue that the ostensive purpose of this regime is to identify "world class" universities, and thus to organize post-secondary education into a competitive transnational market, where, just like in any market, some win and some lose (Cantwell \& Taylor, 2013). Included in our definition of ranking regime are government- 
driven performance and accountability systems, commercial ranking outfits, and similar auditing technologies that scholars have some hand in producing (e.g., journal impact rates).

To date, a growing body of literature has examined the impact of accountability technologies and rankings on the field of higher education at a macro level (Amsler \& Bolsmann, 2012; Cantwell \& Taylor, 2013; Kaba, 2012; Leslie, Slaughter, Taylor, \& Zhang, 2012; Lo, 2011; Marginson, 2007, Pusser \& Marginson, 2013; Shin, Toutkoushian, \& Teicher, 2011). There is a specific and substantial body of work detailing administrative responses to the ranking regime (Bowman \& Bastedo, 2009; 2011; Brint, Riddle \& Hanneman, 2006; Morphew \& Baker, 2004; Sauder \& Epseland, 2009; Taylor $\&$ Morphew, 2010). However, there are few studies showing how the evaluation of faculty and faculty members' production of knowledge might be shaped by this overarching ranking regime.

To this end, this review of literature was motivated by our desire to understand the influence that the ranking regime has on the production of knowledge within academia, which we define as the formation of research projects, the methodologies employed in the research process, and the audiences toward which one's research is directed. The specific question that guided our review and analysis was: What are the implications of the ranking regime for the production of knowledge within academia and for faculty work evaluation? In consideration of this question, we have analytically integrated and synthesized studies that addressed the impact of commercial ranking bodies, quality assessment, or performance measurement on colleges and universities in relation to faculty roles, work practices, and experiences. At the outset, it is important to note that our search was limited to English-language journals, which we could access via Google Scholar and through our institutional library licenses.

To set up the paper, we first provide a basis and rationale for our definition of the "ranking regime," which is somewhat similar to what others have described as an "audit culture" (Power, 2004) or "higher education's accountability movement" (Toutkoushian \& Webber, 2011). Then, we consider two theoretical lenses that are frequently mobilized, although rarely simultaneously, to explain the emergence, power, and consequences of rankings in higher education. First, we consider the utility of Neo-Institutionalism (NI), which presumes a cultural, rather than a rational or economic, explanation for post-secondary organization and actor behavior. Then, we consider neoliberalism, which stresses the link between culture, political economy, and resource allocation for public institutions, like higher education. After outlining the insights from these two theories and describing our literature search approach and method, we present an analytical review of the literature that addresses, either directly or indirectly, how the ranking regime touches upon the work of faculty.

\section{What is the Ranking Regime?}

Our conceptualization of the "ranking regime" suggests an interrelatedness of various kinds of organizations (e.g., government-accountability, accreditation, commercial rankings), which work together to define what excellent higher education, valuable knowledge, or at the grandest level, "world-class universities" are made of. Thus, although most ranking-related scholarship in higher education is focused on commercial ranking outfits like US News and World Report, MacLean's Rankings, Academic Rankings of World Universities or Times Higher Education, we suggest that government-driven accountability, evaluative, and quality assurance agencies perform a very similar function. In this way, commercial rankings, governmental accountability bodies, and similar evaluative entities all claim to measure "excellence," "value," and/or "quality" in order to develop hierarchical, snapshot understandings of college and university performance (Colyvas, 2012; Morley \& Aynsley, 2007; Ramírez, 2013). Accordingly, we use the term "ranking regime" rather than 
“accountability culture" (Toutkoushian \& Webber, 2011) or "audit regime” (Power, 2004) because rankings are intended to communicate a hierarchical organization of the field of higher education.

\section{The Governmental-Accountability Dimension of the Ranking Regime}

As noted above, some of the organizations and agencies that comprise the ranking regime are arms of local, state, and national governments. In fact, higher education scholars have documented that government accountability efforts for higher education have grown and thrived, particularly in the last few decades (Enders, 2004; Shin \& Harman, 2009). Apple (2013) described heightened government accountability efforts in the US and UK as follows:

... across borders, the daily life of faculty members and the content of the curriculum are being steadily transformed by 'audit cultures'. The demand to constantly

'produce evidence' that one is acting correctly - in essence to act in an entrepreneurial manner - has spread ....in the USA, there is now growing pressure on university faculty to enumerate the ways in which their work has 'value added' effects, with legislation mandating this form of evaluation now being considered in a number of state legislatures. (p. 387, emphasis added.

Consistent with Apple's observation, Filappakou (2011) also wrote about the introduction of quality performance measures by the UK government, which assume that "quality" can be captured with a singular definition or measure. Governmental accountability measures are not unique to the UK or US. Asian countries began to adopt accountability measures in the mid-1990s when the demand for higher education from a more diverse student body led to increased higher education costs, at a time when public spending for social goods was declining overall (Shin \& Harman, 2009). Maldonado-Maldonado (2009), Pusser, Kempner, Marginson, and Ordorika (2012), and Torres and Shurgurensky (2002) have also documented the many forms of government-driven accountability across Latin American colleges and universities. Maldonado-Maldonado (2009) described the evaluative turn in Latin American countries and showed how the state-sponsored evaluative bodies often used quantitative measures that were contradictory. Moreover, in countries that might be termed "developing," governmental policy and practices are deeply influenced by entities like "like the World Bank, the Business Forum, and the International Monetary Fund (see Kaba, 2012; Spring, 2008)."

In sum, across the globe, what we call "the governmental dimension of the ranking regime" has been emerging for the last three or four decades, and the literature reviewed in this section offers three main insights. First, government-accountability is often presented as an attempt to reign in public spending. Second, government accountability relies on quantitative, overly simplistic measures of quality. Third, and finally, international entities, like World Bank, are involved in accountability measures and policies, especially in non-Western countries.

\section{The Commercial and Market Dimension of the Ranking Regime}

In addition to efforts sponsored by governments, the ranking regime is also constituted by commercial outfits whose sole purpose is to "rank" post-secondary institutions. Amsler and Bolsmann (2012, p. 285) noted that as far back as 1879, institutional researchers and scholars of education produced comparative data to "rank" students according to professional exam scores and alumni accomplishments. Such early ranking efforts were not intended for government or consumer purposes, but to inform program development. However, between 1980 and 2000, commercial ranking bodies entered the US and UK markets (Amsler \& Bolsmann, 2012).

Early commercial rankings tended to have a domestic focus, but global university rankings began to emerge in the last decade or so. In fact, as of 2013, the European University Association estimated that there were at least 32 ranking bodies that provide international or global comparisons of higher education. Two of the most well-known global ranking systems are Times Higher Education 
(THE) and Academic Ranking of World Universities ( $A R W U$ ), which were launched in 2004 and 2003, respectively. Like domestic ranking bodies, global university rankings purport to provide consumers with information about various higher education providers.

Ramírez (2013) noted that global rankings have a far reach. On this point, Ramírez noted that even in emerging higher education systems, rankings are used to "symbolically communicate high aspirations... [and that] depending on the reference group of countries, the rankings can be used to promote an image of the university as a high-quality establishment or as one striving to attain high international standards" (p. 132). As further evidence of the influence that global rankings wield, Morley and Aynsley (2007) demonstrated that political and economic elites pay attention to the rankings in the development of national educational policy. Specifically, Morley and Aynsley pointed out that such rankings influence investments in particular programming, especially around the issues related to labor force and job readiness. Echoing the interconnectivity between rankings and government, Cantwell and Taylor (2013) wrote that global rankings were developed among "higher education, states, and markets" (p. 196) in order to identify "world-class" universities or "global research universities" (p. 196) and to form a competitive higher education field that operates much like the wider capitalist market, where alliances (or mergers) among super powers promise further power, and the reproduction of inequitable relations (both economic and cultural). This competition hinges on research, knowledge production, and knowledge dissemination, which are measured with impact rates or prestigious appointments that faculty hold due to their discoveries/work. This research focus reflects the privilege that the field of higher education itself has historically allotted to research activity (Clark, 1986; O’Meara, 2011), and for this reason, the global rankings, like THE or $A R W U$, might appeal more to academic audiences than other commercial outfits, like USNWR, because some of the criteria used in global rankings stem directly from academia (evaluation of citations, consideration of impact rates, disciplinary renown).

At this point, we have shown how various kinds of organizations work in similar ways to evaluate and hierarchically organize college and university performance, both domestically and internationally. We also showed how no matter the organization, performance or ranking practices force a narrow measurement higher education. Below, two theoretical perspectives are presented to consider why the ranking regime has risen to such influence.

\section{Theoretical Lenses}

\section{Neo-institutionalism}

Neo-institutionalism was developed in the 1970s to explain organizational behavior and patterns that did not reflect the rational behaviors emphasized in classic organizational theories (DiMaggio \& Powell, 1991; Meyer \& Rowan, 1977). One of the key principles of NI theory is that organizations are situated in particular fields, either cultural or technical (Scott, 1991). Neoinstitutional theorists consider higher education (and education, more generally) a cultural field, because it does not produce goods that are easily or objectively measureable. Unlike an organization that might produce pencils or cars, post-secondary organizations produce knowledge through highly social, interactional, and tacit processes of teaching and learning. Following this line of thinking, neo-institutional scholars stress cultural fields are measured by and interested in the attraction of cultural resources, like legitimacy and prestige, rather than objective or economic resources. On this point, Toma (2012) argued, "prestige is to higher education what profit is to corporations" (p. 118).

If cultural resources like prestige and legitimacy are of primary concern to higher education, two critical matters of concern are: how are cultural resources defined, and how are they rewarded? This brings us to another key tenet of neo-institutional theory, which posits that cultural fields are 
not only difficult to evaluate because of their hard-to-measure production function, but also because they are filled with professionals who are responsible for making such cultural judgments (Deephouse \& Suchman, 2008). For example, Brint and Karabel (1989) demonstrated how research oriented post-secondary institutions in the US have long held a position of privilege and power over other, perhaps vocational or teaching oriented, institutions. They traced this privilege to the history of higher education in the US, the wealth of research-oriented institutions, and their service to a wealthier base as well as judgments made about the value of technical education/teaching by early higher education leaders. Relatedly and directly relevant to the role of faculty, cultural resources for professors are contingent on a scholar's publication record, the establishment of an (inter)national reputation, and media attention (Fairweather, 2005; Rusch \& Wilbur, 2007).”

Taken together, these insights suggest that neo-institutionalism provides a plausible and compelling explanation as to why colleges and universities work hard to attain certain measures of performance, whether it is a better ranking (Tuchman, 2009) or a particular accreditation offered by the state or through a professional organization (Rusch \& Wilbur, 2007). In short, these sorts of accomplishments offer up cultural resources, like legitimacy and prestige, to organizations that rely on such tacit measures of success. Following this line of thinking, neo-institutionalism also offers a reason for the power of global rankings, especially since many of the measures utilized in rankings are actually measures that academics themselves developed for use within academia. For example, Hart and Metcalfe (2010) demonstrated how impact and citation rates are highly valued in the evaluation of a professor's activities, and recall that the most well-known global rankings, like THE or $A R W U$, rely on such measures, as detailed by Ramírez (2013).

Neoinstitutionalism helps to illuminate how and why the ranking regime might elicit compliance from post-secondary organizations and their constituent actors. However, it has little to say about the fact that some of these cultural measures, originally developed by academics for academic professional judgment (citation rates, for example), are now used by commercial outfits, and for the express purpose of creating a higher education field that behaves more like a market. As we argue in the next section, the perspective of neoliberalism helps us to understand these more recent developments.

\section{Neoliberalism}

While neo-institutionalism suggests that rankings confer cultural resources like legitimacy and prestige upon colleges and universities, neoliberalism helps one to see how these cultural resources have come to be connected to the dynamics of the political economy. In short, neoliberalism is an approach to public policy that centers the principles of the free market and simultaneously deemphasizes the utility of governmental oversight or public investment in public goods (Harvey, 2005). In this way, a critical assumption of neoliberalism is that all activities and goods can and should be measured for comparative and competitive purposes (Gonzales \& Martinez, 2014; Stratilatis, 2014).

According to Harvey (2005), neoliberalism represented a shift from capitalism because it was an approach to political-economic policy intentionally facilitated by multiple national powers (China, England, and the US). In terms of higher education, this led North American, Latin American, Asian, and European countries to position higher education as a private market good, where students were framed as consumers and faculty as academic laborers, as opposed to participants in the teaching and learning experience (Mumper, Gladieux, King, \& Corrigan, 2011; Shin \& Harman, 2009). Drawing from such insights, Slaughter and Leslie (1997) developed the theory of academic capitalism to help explain how these policy moves impacted the operation of Australian, British, and US colleges and universities. They asserted that college and university leaders asked (and rewarded) 
faculty to serve political and industry elites via their research programs. Slaughter and Leslie also showed that in this context, intellectual labor and faculty work were suddenly considered valuable for their revenue potential. Slaughter and Rhoades (2004) later revised "academic capitalism" to show how college and university leaders and academics were no longer merely responding to external political and economic environments, but had become active in promoting neoliberal values and norms from within academia.

Slaughter and Rhoades (2004) argued that a significant consequence of neoliberalism is its effect on how people understand the world and how it should operate. Slaughter and Rhoades suggested that the principles of neoliberalism (e.g., free-market, competition, education for labor market) become so engrained in how one thinks through processes, activities, and decisions that they come to serve as a difficult-to-question logic. Following this line of thinking, Davies et al., (2004) explained that neoliberalism works through "technologies of regulation and compliance [that] are expanded, and more tightly codified, measured, scrutinised, assessed, rewarded and punished" (p. 673 ) in the name of efficiency, utility, and general market sensibilities.

Applying these insights to higher education, the rise (and hold) of the ranking regime becomes clearer: colleges and universities are treated as markets by governments, and associate ranking regime conformity as a way to generate fiscal resources. Furthermore, the logic of ranking, measuring, evaluating, and even competing has become normalized in this neoliberal moment. In this way, it seems acceptable, and even normal, to measure and rank tacit cultural processes, like the work that unfolds within teaching, learning, research, and knowledge production.

On this note, there is a notable connection between neoliberalism and the privileging of a scientific epistemology (Pasque, Carducci, Kuntz, \& Gildersleeve, 2012; Stratilatis, 2014). Writing over three decades ago, Bleicher (1982) asserted that markets and science are tightly linked, since markets often thrive from developments and innovation derived from science. Moreover, the larger public views science and the associated scientific method as trustworthy and progressive, which helps to explain why the ranking regime is accepted as a way to gauge college and university performance. In other words, the ranking regime is normalized because of the epistemological orientations from which it is built and which circulate through society on a massive scale, particularly in the West.

In sum, we have stressed three major insights from the theoretical discussion of neoliberalism: (a) that government is only useful in providing the kind of framework necessary to engender a market-like environment; (b) that all goods and activities can and should be treated as if they have an exchange value; and (c) that a scientific epistemology is a legitimate and most suitable way to measure tacit phenomena such as college and university performance, faculty performance, teaching and learning, and so forth. Thus, while neo-institutionalism advances a cultural resource theory about rankings with little attention to the political economy, neoliberalism compels one to consider that the ranking regime extends beyond a cultural resource game, or even more interestingly, that it exploits what was once a cultural resource game in order to advance the neoliberal project.

\section{Research Design \& Data Sources}

Having reviewed two theoretical interpretations of the ranking regime, we now turn to our research design, which is an integrative analysis of literature (Cooper \& Hedges, 2009). An integrative analysis brings together studies from multiple disciplines in order to view a complex topic from a new lens. As we searched for literature, we selected sources that responded to the following question in some fashion: "What are the implications of the ranking regime for the production of 
knowledge within academia and for the evaluation of faculty work?” Next, we specifically describe our selection of literature.

\section{Selection of Literature}

As higher education scholars who have examined the academic profession, the influence of rankings on university behavior, and faculty evaluation, we had a working knowledge of the current literature concerning this topic. To begin our literature review, we made a list of potential articles and authors that address this topic. This is a typical first step for an integrative review of literature (Cooper \& Hedges, 2009). Our initial list was composed mostly of higher education studies based in the US, Canada, the UK, Australia, as well as a few studies about Asian and Latin American higher education.

We then developed a list of keywords/combinations of key words reflected in this initial set of literature. These keyword combinations included: "accountability," "academia," "audit culture," "faculty work," "faculty rewards," "higher education," "rankings," and "neoliberalism." We used these keywords/combinations to search academic journal databases and Google Scholar. As we identified potential sources, we asked ourselves, "Does this source help us understand how faculty work, especially the production and evaluation of knowledge, might be influenced by the ranking regime, as we have defined it?" Our search was international in scope in that we looked for articles that addressed government accountability or rankings across the globe. Using these various search strategies, we considered almost 160 articles in English language journals. In this paper, we have included the sources that seemed most relevant to our research questions.

\section{Analytical Process}

The following questions focused our analysis: (a) What does the literature suggest about how the ranking regime influences the evaluation of scholarship or knowledge production?; (b) What does the literature suggest about how faculty approach their work in response to the rankings regime?; (c) How might the ranking regime influence faculty dissemination of their scholarship?; and (d) How might faculty respond to concerns about the evaluation or legitimacy of their scholarship in relation to the ranking regime? As we examined the literature in light of these questions, we considered the perspectives offered by each of our theoretical lenses.

\section{Trustworthiness}

Given the interpretive nature of this work, we have followed the standard of trustworthiness (Cooper \& Hedges, 2009). Trustworthiness is achieved through strategies of transparency and triangulation (Maxwell, 1992). Thus, we detailed our selection of literature and we explicitly articulated the theoretical lenses that helped us think about this problem, which are key to an integrative analysis (Cooper \& Hedges, 2009). Finally, we worked independently on the review and analysis of literature and came back together to subject one another's thinking to critique and triangulation.

\section{Findings and Discussion}

Our synthesis of the literature suggests that the rankings regime does, indeed, yield influences on the evaluation of faculty work, especially knowledge production, through the perpetuation of the following values or practices: (a) individualism; (b) standardization; (c) commodification; and (d) homogenization.

Concerning individualism, we argue that the ranking regime is structured and monitored in ways that encourage individual achievement. Individualism means that faculty work is oversimplified 
into singular products or processes and represented by singular marks, which enable standardization. Standardization simplifies and decontextualizes faculty work and knowledge production enough so that they become comparable. Comparison, with the implication of competition, implies the commodification of one's work as a product with exchange value. Finally, we offer evidence that the ranking regime emphasizes or assigns more value to certain types of faculty contributions, which we argue facilitates homogenization as it relates to the production and dissemination of knowledge. Table 1 summarizes each of these findings. As we discuss each of these findings, we also explore how faculty members respond to the implications of these themes, keeping in mind that not all faculty respond in the same way.

Table 1

Meaning of themes in the findings

\begin{tabular}{ll}
\hline \multicolumn{1}{c}{ Finding } & \multicolumn{1}{c}{ Meaning } \\
\hline Individualism & Encourages individual competition through various evaluative technologies. \\
Standardization & Requires the evaluation of faculty work with decontextualized, universal measures. \\
Commodification & $\begin{array}{l}\text { Utilizes the standardized information collected through evaluative technologies to compare the } \\
\text { contributions of faculty. } \\
\text { Awards recognition narrowly to particular forms of faculty work, especially particular publishing } \\
\text { Approaches. }\end{array}$ \\
\hline
\end{tabular}

\section{Individualism}

The practice of ranking, by its very nature, pits individuals and institutions against one another. This happens in a few ways. First, ranking and evaluative exercises typically account for the extent to which scholars publish as sole authors (Pasque, Carducci, Gildersleeve, \& Kuntz, 2011; Ramírez, 2013). Second, ranking and evaluative systems require that faculty members document carefully the work they have conducted as an individual. This process includes recording the percentage that they contribute to any collaborative project (Archer, 2008; Pasque et al., 2011) or reporting individual achievements like sole publications, disciplinary awards, and research related recognition (Ramírez, 2013). Furthermore, this reporting can be undertaken not only at the university, but also at the national level. For example, Musselin (2013) described how "in France, legislators adopted a decree modifying the status of faculty members in 2009, which introduced regular individualized evaluations of all faculty members" (p. 1166) while in Spain, "faculty members have undergone individualized evaluation since the 2000s" (p. 1166). In both countries, these evaluative processes have then been linked to compensation.

When solo efforts are emphasized, competition and individualism increases, and sense of community among faculty is diminished. Like most scholars, we are skeptical of a "golden era" where a community of scholars (Goodman, 1962) ever truly operated, yet it is important to note the heightened sense of isolation that is yielded by competitive environments. Ylijoki's (2005) study provided insight into academic life in Finland, where competition and market-centered values have increased in recent years. One faculty member in Ylijoki's study described:

...people are pretty much in a hurry and have withdrawn into their own research without taking notice of what is happening around them. You really don't have much contact with other researchers...And what suffers from that is the general intellectual spirit that should prevail in such environments. It should prevail here as it used to do when I came to the department [when]...researchers might spend many hours in the afternoons discussing scientific matters from all sides and in a good spirit. At present this does not happen at all. (pp. 555-556) 
Moreover, Gonzales (2012) studied faculty experiences in one university striving to win the top seat in a state-designed ranking system, and found that the majority of faculty were putting more distance between themselves and the university setting in order to focus on their own researchoriented professional endeavors. These examples suggest that ranking and accountability cultures promote neoliberal environments where "there is no space for collectivity" (Osei-Kofi, 2012, p. 237).

Relatedly, Kenneth González (2008) described how individual achievement is prized in most tenure and promotion processes, which use many of the criteria (research record, impact rates, and individual reputation/impacts) now measured by ranking bodies. González noted that individualism challenges faculty who want to use their work to advance a broader, communal good. He reflected on how, during his own process of earning tenure, he postponed his desire to serve local Latino communities and deferred to discipline based norms and approaches to inquiry. In line with neoinstitutional theory, González expressed concern that if his work was not anchored in more common or legitimized and disciplinary-defined theories or approaches, it might not be wellreceived among colleagues.

\section{Standardization}

The rankings regime also engenders generic, or what we call standardized, approaches to measuring faculty and institutional characteristics and activities. In fact, standardization is a hallmark of the accountability movement throughout education (Ball, 2003; Martínez Alemán, 2012). Standardization enables comparisons of wildly different settings and contexts in order to gauge universities and colleges by single definitions of quality or excellence. The European University Association (2013) offered the following cautionary note to university leaders and policy makers:

...global rankings are no longer a concern only for a small number of elite institutions but have become a reality for a much broader spectrum of universities as they seek to be included in, or improve their position in one or the other rankings. This means that they have started to shape the development of higher education systems as such, which is a significant shift bearing in mind that most international rankings in their present form still only cover a very small percentage of the world's 17,500 universities... with little consideration given to the rest. (p. 6)

Standardization facilitates the collection of information that ranking bodies need to form the basis of their hierarchical evaluations. With regard to the evaluation of faculty work, one very common standardization practice is the heavy reliance on bibliometric data. Of this tendency, Safón (2013) noted that ranking bodies define quality by the number and prestige of publications and grants awards that a university's faculty obtains. Specifically, ranking bodies count faculty publications and give additional points to what they recognize as "top-tier" journals (Linton, Tierney, \& Walsh, 2011). This approach to the evaluation of faculty careers is problematic because it assumes that a valuable or standard faculty profile should be dominated by research activity. Furthermore, research suggests that when an institution intends to climb a ranking system, the approach to faculty evaluation skews heavily towards research and publications (Gonzales, 2013; Henderson, 2009; O’Meara \& Bloomgarden, 2011).

Importantly, however, academics themselves have had a hand in the privilege allotted to research, especially the emphasis on certain dissemination strategies. For example, Bray and Major (2011) asked faculty members within the field of higher education to list a number of predetermined journals as "first tier (high level of prestige), second tier (good level prestige), third tier (moderate level of prestige), and fourth tier (low level of prestige)" (p. 479). Their analysis revealed two key findings: (a) top-tier journals were general in terms of content and mostly associated with 
U.S.-based studies/audiences, whereas (b) journals in lower tiers tended to be more specialized and included several that focused on issues related to student development and to promoting opportunities for students and college personnel from different social and economic backgrounds (e.g., college counseling, teaching and learning, community colleges, Hispanics in higher education). Furthermore, according to members in Bray and Major's (2011) study, faculty cited first-tier journals at an above average rate. Meanwhile, two-thirds of the entire group of journals were cited by fewer than one in eight $(12.5 \%)$ faculty members. This suggests that these faculty members read, aim to publish in, and cite a standard set of top-tier journals.

These findings can be interpreted in at least two ways. One could argue that the "higher prestige" journals are general or broad enough to feature a diverse and broad array of issues, meaning faculty might name these journals as high prestige because they believe they welcome diverse topics, theories, and methods. However, empirical evidence challenges this optimistic interpretation. Specifically, the top tier journals in the higher education field have historically published little feminist scholarship, race/ethnicity-oriented work, qualitative work, or work that interrogates systems of inequality from a structural perspective (Harper, 2012; Hart; 2006; Hart \& Metcalfe, 2010; Stanley, 2007).

The ranking regime can also apply dynamics of standardization to teaching. Although student evaluations have historically been conducted as a worldwide practice with both formative and summative aims, the summative purpose of such evaluations has increasingly been emphasized (Spooren, Brockx, \& Mortelmans, 2013). As Spooren et al. (2013) point out, "the principal purpose of [student evaluation] involves its use as a measure for quality monitoring, administrative policymaking... for determining whether teachers have achieved a required standard in their teaching practice" (p. 2). At the outset, meeting a "required standard" seems a laudable goal, but meeting or judging to a standard requires the assumption that resources, culture, and socio-political contexts do not matter. Additionally, it assumes that teaching and learning can actually be measured with some standard snapshot indicator (Alemán, 2012). Furthermore, substantial research suggests that the validity and value of student evaluations is very questionable and inconclusive, and that limited (if any) conclusions about the quality of teaching can be drawn from these evaluations (Spooren et al., 2013).

An example of Kyrgyz higher education illustrates how the dynamics of standardization can play out from a national-international level. Specifically, after the Soviet Union's collapse, the Kyrgyz government attempted to infuse its higher education system with qualities that it deemed "firstworld," in order to shed its "third-world" image (Amsler, 2012). Consequently, higher education faculty and administrators across the country searched for universal measures to determine standardized models of teaching and learning that could prepare Krygryz students to compete in a global or knowledge economy. Amsler (2012) documented that this process resulted in further standardization of student admission policies and practices, in addition to curricular designs and interventions.

In sum, standardization represents an attempt to establish universal value for quality, value, excellence, and prestige (and so on) within higher education. Standardization allows for comparison and competition of one's goods, which is discussed next.

\section{Commodification}

As noted earlier, it seems that standardization is a necessary precursor to commodification. Commodification "refers to the process of turning social goods and processes (as well as people) into commodities" (Canaan \& Shumar, 2011, p. 4), so that they may be inscribed with a use, exchange, and surplus values. It is necessary to standardize items as they are placed as commodities 
into a competitive market place. The commodification of faculty work seems to be facilitated in a number of ways. For one, grant-getting is a key strategy in the commodification of knowledge production (Slaughter \& Rhoades, 2004). Research on U.S. institutions striving to move "up" in the rankings have found that faculty in these institutions often feel pressured to or actually do reallocate time. Specifically, faculty in such settings might prioritize research and/or grant-writing since grant money and industry partnerships are important in light of the university's desire to earn a higher ranking (Gonzales \& Martinez, 2014). Observers note that such trends are not limited to the U.S., but are intensifying worldwide (Metcalfe, 2010; Pusser \& Marginson, 2013). To this point, one of the effects of commodification is that knowledge loses its intrinsic value as it gets inscribed with market values (Beck \& Young, 2005). Furthermore, as knowledge is inserted into the market, its "use value" is contingent on the kind of marketplace it occupies. In the classroom, even if the teaching and learning process inspires dynamic, rich, and engaging knowledge production and exchange, ranking or evaluative bodies have no tool to capture that.

On the other hand, as academics produce more knowledge/research to keep up with the growing demands of research productivity encouraged by tenure and promotion processes and university attendance to rankings, the "value" of such work declines. Just as with any market good, the quantity or supply of the good influences its exchange value (Rhoades \& Slaughter, 1997). In turn, faculty members might cognitively commodify their own work as they think about scholarship in terms of quantity, pace of production, and competition. In the most explicit cases of commodification, faculty work is translated into numerical and dollar figures for the purposes of evaluating faculty. For example, Davies and Bansel (2010) reported that "in Australian universities, a book's worth is uniformly calculated as 6 points (less if it is an edited book) and points are made meaningful [by] being given dollar values, which in turn translates into government funding to the university.... and research status" (p. 6).

The studies cited here suggest that the ranking regime enables the commodification of knowledge and faculty work, overall. Commodification means that one's work is placed in the market, where some forms of work are ascribed more value than others. Next, we explore how this can yield a homogenization of approaches to faculty work as well as knowledge production itself.

\section{Homogenization}

Standardization and commodification can contribute to the homogenization of knowledge, as together these perpetuate narrow notions of "quality" faculty work. For example, the European University Association (EUA, 2013) reports that nearly all of the 32 international rankings systems emphasize faculty research productivity, publication impact, and citation rates. Additionally, the EUA report explained that favor is very typically given to English language research publications, because:

... [previous] research has clearly demonstrated that publications in languages other than English are read by fewer researchers than those in English from the same universities... The result is that the non-English-language output of these universities has a lower citation impact and thus a lower position in the ranking. (p. 19)

With such an incentive, faculty in European universities may be more likely to publish in English, and their institutions may encourage them to do so as well in order to move up in the rankings (Kaba, 2012). This finding is even more powerful and convincing in light of Lo's (2011) finding that the vast majority of the highest ranked institutions in the 2009 Times Higher Education-QS (THE) were geographically concentrated in the West, where the United States has 54 universities and the United Kingdom had 29 universities in the rankings. Lo explained, "six out of every ten universities on the top 200 list were located in countries that were at one time partly or fully 
colonized by the United Kingdom” (p. 1).

In sum, the themes that emerged based on our analysis of existing literature - individualism, standardization, commodification, and homogenization - fail to recognize the multiple professional activities that faculty undertake in colleges and universities, including the tacit and dynamic exchanges involved in teaching and learning, dialoguing with colleagues inside and outside of academia to solve problems or provide service of some sort to society, and engaging in timeintensive student and peer mentoring and advising. When the ranking regime does recognize or attempt to account for excellence in teaching, for example, it relies on narrow and universal measures of value (Brint, 2011; Spooren et al., 2013). On the other hand, the ranking regime clearly privileges research activities and productivity in very specific ways: in ways that favor the use of English in scholarly dissemination (at least in the US and Europe); in ways that uphold the dominance of disciplines and what seems to be narrow valuation of knowledge; and in ways that favor dissemination strategies to academic instead of broader audiences.

\section{Implications}

In this paper, we reviewed how the ranking regime, which is intimately connected to the desire among colleges and universities to establish themselves as "world class" universities, is shaping faculty work and roles, the production of knowledge, and faculty evaluation, overall. To address this question, we surveyed a broad, interdisciplinary body of existing literature. Considering our findings in light of neo-institutionalism and neoliberal lenses, we can draw the following implications.

This review reveals that the rankings regime perpetuates values of individualism and standardization among faculty members to account for excellence (Ramírez, 2013) in their work. Further, it indicates that the ranking regime's emphasis on certain faculty activities like research, publication, and grant-getting enables the commodification of faculty work, a process in which faculty are distanced from the value assigned to their work, as it is turned into a product with exchange value. Finally, it illustrates how the ranking regime can lead to homogenization of knowledge production. These findings suggest that cultural resources traditionally emphasized in higher education institutions have come to serve the global political economy in ways that neoinstitutionalism has traditionally not accounted for.

On this point, the neo-institutional lens is valuable for understanding the ranking regime because it points to the hand that the profession and the field have had in crafting the rules for cultural resources, which are now leveraged for very different purposes. Whereas these rules for faculty evaluation were once crafted as rules to guide the academic profession, these cultural resource rules now function as currency in a global, transnational competition among higher education institutions. And just as in all competitive markets, there are winners and there are losers. For the most part, it seems that winners include those institutions and those countries with historical privilege and resources, and longer higher education legacies. Cultural resources were, after all, first defined in such spaces, and so they have a head-start, so to speak. Kaba (2012) demonstrated this point well when he showed that rankings merely reproduce and reflect the imperial legacies of Western, English-speaking, capitalist countries. We believe that our synthesis of literature reinforces Kaba's argument in significant ways.

By blending insights from neo-institutionalism and neoliberalism, we can see how the ranking regime is successful because it is constructed with some of the cultural resource rules that long guided higher education. We argue that these cultural resource rules have come to be used for "neoliberal practices of regulation [that] suppress consideration of power, control, and interest" in 
higher education (Davies \& Bansel, 2010, p. 6). Following this line of thinking, in a politicaleconomic moment when government no longer views higher education as a public good, colleges and universities quickly become subject - and indeed look for ways - to increase resources, in various ways. We argue that the cultural resource disposition of higher education has become coopted by neoliberalism.

Future research should investigate the extent to which accounting for excellence has intensified in academia, particularly since the neoliberal era emerged in the 1980s. Careful work needs to be focused on those universities and colleges that have declared intent to strive up the rankings or achieve an accreditation or some notable measure of performance to trace, empirically, the shifts in faculty behaviors. Oral histories with faculty who have been in the academy for longer and can reflect on their experiences over time could illuminate the extent to which these shifts have shaped their lives as academics, including whether increasing pressure to conduct research and particular kinds of research compromised their own willingness/capacity to engage particular theoretical or methodological approaches, their publication habits, or the ability to advance the public good. Further investigating whether and how methods of reporting for promotion and tenure have changed over time would also provide insights into the influence of the ranking regime. Finally, exploring the extent to which lists of "top-tier" or "core" journals remain stable over time and whether they increase or decrease in number and type could also contribute to our understanding of how the ranking regime affects knowledge production.

With respect to policy, this review suggests that universities and colleges should be proactive in considering how they might re-shape definitions of accountability, value, or excellence to incorporate interests of the public good. This could mean following the practice among some institutions, such as the University of California, to call for increased recognition of public engagement and community service activities in the tenure and promotion process (Hurtado \& Sharkness, 2008). The US-based Carnegie Community Engagement Classification System (http://classifications.carnegiefoundation.org/descriptions/community_engagement.php) is another way that universities might consider measuring and reporting on their activity. Being atop this ranking suggests that colleges and universities are highly involved in local communities through partnerships, volunteer and civic engagement, or action/applied research.

Our review yields additional policy implications. Namely, these findings have relevance for tenure and promotion committees, as well as larger faculty governance bodies within universities. Faculty could consider these thematic findings as they develop or refine tenure and promotion, hiring, or resource allocation practices. For example, tenure and promotion committees can intentionally develop a reward system that recognizes faculty for working with local schools, hospitals, or other organizations; such efforts are likely to be documented in small action research efforts, policy briefs, or evaluative reports (Ellison \& Eatman, 2008; Sandmann, Saltmarsh, \& O'Meara, 2008). In this way, we argue that because faculty have helped to empower some of the most powerful metrics that drive the ranking regime, especially global ranking bodies, faculty also have the opportunity to develop alternative ways to consider and reward faculty work.

In closing, we acknowledge that the state of higher education and faculty work that we have portrayed makes it difficult, and some might even say impossible or unwise, to construct one's career in ways that do not align to the ranking regime. However, studies have illustrated the capacity for faculty resistance to neoliberal forces and associated narrow constructions of prestige or legitimacy (e.g., Archer, 2008; Huckaby, 2008; Gonzales \& Martinez, 2014). Some of the most powerful and sustainable examples of resistance are often nurtured through collaborative faculty networks explicitly committed to egalitarian approaches to scholarship that challenge the norms of individualism, standardization, commodification, and homogenization (Carducci, Kuntz, 
Gildersleeve, \& Pasque, 2011; Núñez \& Murakami, 2012). Also, mentoring graduate students and faculty to adopt critical approaches to faculty roles and purposes, and to engage in diverse dissemination strategies are other ways that scholars might be able to resist or challenge the power of the ranking regime.

\section{References}

Alemán, A. M. (2012). Accountability, pragmatic aims, and the American university. New York: Routledge.

Amsler, S. (2012). Higher education reform in post-Soviet Kyrgyzstan: The politics of neoliberal agendas in theory and practice. In J.E. Canaan \& W. Schumar (Eds). Structure and agency in the neoliberal university, (pp. 101-130), New York, NY: Routledge.

Amsler, S. S., \& Bolsmann, C. (2012). University ranking as social exclusion. British Journal of Sociology of Education, 33(2), 283-301. http:/ /dx.doi.org/10.1080/01425692.2011.649835

Apple, M. (2013). Audit cultures, labour, and conservative movements in the global university. Journal of Educational Administration and History, 45(4), 385-394. http:/ / dx.doi.org/10.1080/00220620.2013.822349

Archer, L. (2008). The new neoliberal subjects? Young/er academics' constructions of professional identity. Journal of Education Policy, 23(3), 265-285. http:/ /dx.doi.org/10.1080/02680930701754047

Ball, S. J. (2003). The teacher's soul and the terrors of performativity. Journal of education policy, 18(2), 215-228. http:/ / dx.doi.org/10.1080/0268093022000043065

Beck, J., \& Young, M. F. (2005). The assault on the professions and the restructuring of academic and professional identities: a Bernsteinian analysis. British journal of sociology of education, 26(2), 183-197. http://dx.doi.org/10.1080/0142569042000294165

Bleicher, J. (1982). The hermeneutic imagination: Outline of a positive critique of scientism and sociology. London: Routledge \& Kegan Paul.

Bowman, N. A., \& Bastedo, M. N. (2009). Getting on the front page: Organizational reputation, status signals, and the impact of U.S. News and World Report on student decisions. Research in Higher Education, 50, 415-436. http:// dx.doi.org/10.1007/s11162-009-9129-8

Bray, N. J., \& Major, C. H. (2011). Status of journals in the field of higher education. Journal of Higher Education, 82(4), 479-503. http://dx.doi.org/10.1353/jhe.2011.0020

Brint, S. (2011). Focus on the classroom: Movements to reform college teaching and learning, 19802008. In J. Hermaowicz (Ed.) The American academic profession: Transformation in contemporary higher education, (pp. 44-91). Baltimore, ML: John Hopkins University Press.

Brint, S., \& Karabel, J. (1989). The diverted dream: community colleges and the promise of educational opportunity in America, 1900-1985. New York, NY: Oxford University Press.

Brint, S., Riddle, M., \& Hanneman, R. A. (2006). Reference sets, identities, and aspirations in a complex organizational field: The case of American four-year colleges and universities. Sociology of education, 79(3), 229-252. http:/ / dx.doi.org/10.1177/003804070607900303

Canaan, J. E., \& Shumar, W. (Eds.). (2011). Structure and agency in the neoliberal university. New York, NY: Taylor \& Francis.

Cantwell, B., \& Taylor, B. J. (2013). Global status, intra-institutional stratification and organizational segmentation: A time-dynamic tobit analysis of ARWU position among US universities. Minerva, 51(2), 1-29. http://dx.doi.org/10.1007/s11024-013-9228-8 
Carducci, R., Kuntz, A., Gildersleeve, R.E., \& Pasque, P. (2011). The disruptive dialogue project: Crafting critical spaces in higher education. InterActions,7(2). Retrieved from: http://escholarship.org/uc/item/7mf1j9mn.

Clark, B. R. (1986). The higher education system: Academic organization in cross-national perspective. Berkeley, CA: University of California Press.

Colyvas, J. A. (2012). Performance metrics as formal structures and through the lens of social mechanisms: when do they work and how do they influence?. American Journal of Education, 118(2), 167-197. http://dx.doi.org/10.1086/663270

Cooper, H. \& Hedges, L. V. (2009). Research synthesis as a scientific process. In Cooper, H., Hedges, L., \& Valentine, J. C. (Ed.), The handbook of research synthesis and meta-analysis (pp. 317). New York, NY: Russell Sage Foundation.

Davies, B., \& Bansel, P. (2010). Governmentality and academic work: Shaping the hearts and minds of Academic workers. Journal of Curriculum Theorizing, 26(3), 5-20.

Davies, B., Browne, J., Gannon, S., Honan, E., Laws, C., Mueller-Rockstroh, B., \& Peterson, E. (2004). The ambivalent practices of reflexivity. Qualitative Inquiry, 10(3), 360-391. http://dx.doi.org/10.1177/1077800403257638

Deephouse, D. L., \& Suchman, M. (2008). Legitimacy in organizational institutionalism. In R. Greenwood, C. Oliver, K. Sahlin, \& R. Suddaby (Eds). The Sage handbook of organizational institutionalism, (pp. 49-77) Thousand Oaks, CA: Sage Publications. http:/ /dx.doi.org/10.4135/9781849200387.n2

DiMaggio, P. J., \& Powell, W. W. (Eds.). (1991). The new institutionalism in organizational analysis. Chicago, IL: University of Chicago Press.

Ellison, J. \& T. K. Eatman. (2008). Scholarship in public: Knowledge creation and tenure policy in the engaged university. Syracuse, NY: Imagining America.

Enders, J. (2004). Higher education, internationalisation, and the nation-state: Recent developments and challenges to governance theory. Higher education, 47(3), 361-382. http:/ / dx.doi.org/10.1023/B:HIGH.0000016461.98676.30

European University Association. (2013). Global university rankings and their impact: Report II. Brussels, Belgium.

Fairweather, J. S. (2005). Beyond the rhetoric: Trends in the relative value of teaching and research in faculty salaries. The Journal of Higher Education, 76(4), 401-422. http:/ /dx.doi.org/10.1353/jhe.2005.0027

Filippakou, O. (2011). The idea of quality in higher education: a conceptual approach. Discourse: Studies in the Cultural Politics of Education, 32(1), 15-28. http:/ / dx.doi.org/10.1080/01596306.2011.537068

Gonzales, L. D. (2013). Faculty sense-making and mission creep: Interrogating institutionalized ways of knowing and doing legitimacy. Review of Higher Education, 36(2), 179-209. http:/ / dx.doi.org/10.1353/rhe.2013.0000

Gonzales, L. D. (2012). Faculty responses to mission creep: Cosmopolitan views and actions. Higher Education, 64(3), 337-353. http:/ / dx.doi.org/10.1007/s10734-011-9497-9

Gonzales, L. D. \& Martinez, E. (2014). Possibilities and responsibilities: How faculty talk can (de)construct rankings and university striving. Journal of Critical Thought and Praxis, 2(2), doi: http://lib.dr.iastate.edu/jctp/vol2/iss2/2

González, K. (2008). In search of praxis: Legacy making in the aggregate. K. González and R. Padilla (Eds.) Doing the public good: Latina/ o scholars engage civic participation, (pp. 125-135), Sterling, VA: Stylus.

Goodman, P. (1962). The community of scholars. New York: Random House. 
Harper, S. (2012). Race without racism: How higher education researchers minimize racist institutional norms. Review of Higher Education, 36(1), 9-30. http:/ / dx.doi.org/10.1353/rhe.2012.0047

Hart, J. (2006). Women and feminism in higher education scholarship: An analysis of three core journals. The Journal of Higher Education, 77(1), 40-61. http://dx.doi.org/10.1353/jhe.2006.0003

Hart, J., \& Metcalfe, A. S. (2010). Whose web of knowledge ${ }^{\mathrm{TM}}$ is it anyway?: Citing feminist research in the field of higher education. The Journal of Higher Education, 81(2), 140-163. http:/ / dx.doi.org/10.1353/jhe.0.0083

Harvey, D. (2005). A brief history of neoliberalism. New York, NY: Oxford University Press.

Henderson, B. B. (2009). Mission creep and teaching at the Master's university. College Teaching, 57(4), 185-187. http://dx.doi.org/10.1080/87567550903218497

Huckaby, M. F. (2008). Making use of Foucault in a study of specific parrhesiastic scholars. Educational Philosophy and Theory, 40(6), 770-788. http://dx.doi.org/10.1111/j.14695812.2007.00369.x

Hurtado, S., \& Sharkness, J. (2008). Scholarship is changing, and so should tenure review. Academe, 94(5), 37-39.

Kaba, A. J. (2012). Analyzing the Anglo-American hegemony in the Times Higher Education Rankings, Education Policy Archives Analysis 20(21) Retrieved [November 2013] from, http://epaa.asu.edu/ojs/article/view/847.

Leslie, L. L., Slaughter, S., Taylor, B. J., \& Zhang, L. (2012). How do revenue variations affect expenditures within US research universities? Research in Higher Education, 53(6), 614-639. http:/ / dx.doi.org/10.1007/s11162-011-9248-x

Linton, J. D., Tierney, R., \& Walsh, S. T. (2011). Publish or perish: How are research and reputation related? Serials Review, 37(4), 244-257. http://dx.doi.org/10.1016/j.serrev.2011.09.001

Lo, W. Y. W. (2011). Soft power, university rankings and knowledge production: Distinctions between hegemony and self-determination in higher education. Comparative Education, 47(2), 209-222. http://dx.doi.org/10.1080/03050068.2011.554092

Maldonado-Maldonado, A. (2009). Latin American higher education: Hope in the struggle? in D. Palfreyman \& T. Tapper (Eds.) Structuring mass higher education: The role of elite institutions, (pp. 73-94), New York, NY: Routledge.

Marginson, S. (2007). University mission and identity for a post post-public era. Higher Education Research \& Development, 26(1), 117-131. http:/ / dx.doi.org/10.1080/07294360601166851

Martínez Alemán, A. M. (2012). Accountability, pragmatic aims, and the American university. New York: Routledge.

Maxwell, J. A. (1992). Understanding and validity in qualitative research. Harvard Educational Review, 62(3), 279-301.

Metcalfe, A. (2010). Examining the trilateral networks of the triple helix: Intermediating organizations and academy-industry-government relations. Critical Sociology, 36(4), 503-519. http:/ /dx.doi.org/10.1177/0896920510365920

Meyer, J. W., \& Rowan, B. (1977). Institutionalized organizations: Formal structure as myth and ceremony. American journal of sociology, 83(2), 340. http:/ /dx.doi.org/10.1086/226550

Morley, L., \& Aynsley, S. (2007). Employers, quality and standards in higher education: shared values and vocabularies or elitism and inequalities?. Higher Education Quarterly, 61(3), 229-249. http:/ / dx.doi.org/10.1111/j.1468-2273.2007.00353.x 
Morphew, C. C., \& Baker, B. D. (2004). The cost of prestige: Do new research I universities incur higher administrative costs?. The Review of Higher Education, 27(3), 365-384. http://dx.doi.org/10.1353/rhe.2004.0005

Mumper, M. Gladieux, L.E., King, J.E., \& Corrigan, M.E. (2011). The federal government and higher education in P.G. Altbach, P. J. Gumport, \& R.O. Berdahl (Eds.) American higher education in the twenty-first century - Social, political, and economic challenges, $3^{\text {rd }}$ edition, (pp. 113-138), Baltimore, ML: John Hopkins University Press.

Musselin, C. (2013). Redefinition of the relationships between academics and their university. Higher Education, 65(1), 25-37. http:/ / dx.doi.org/10.1007/s10734-012-9579-3

Núñez, A.-M., \& Murakami-Ramalho, E. (2012). The demographic dividend: Why the success of Latino faculty and students is critical. Academe, 98(1), 32-37.

O'Meara, K. (2011). Inside the panopticon: Studying academic reward systems (p. 161-220) In J.C. Smart, M.B. Paulsen (eds.), Higher Education: Handbook of Theory and Research, 26. New York: Springer. http://dx.doi.org/10.1007/978-94-007-0702-3_5

O’Meara, K. \& Bloomgarden, A. (2011). The pursuit of prestige: The experience of institutional striving from a faculty perspective. The Journal of the Professoriate, 4(1), 39-72.

Osei-Kofi, N. (2012). Junior faculty of color in the corporate university: implications of neoliberalism and neoconservatism on research, teaching, and service. Critical Studies in Education, 53(2), 229-244. http:/ / dx.doi.org/10.1080/17508487.2012.672326

Pasque, P., Carducci, R., Gildersleeve, R. \& Kuntz, A. (2011). Disrupting the ethical imperatives of "junior" critical qualitative scholars in the era of conservative modernization.

Qualitative Inquiry, 17(7), 571-588. http:// dx.doi.org/10.1177/1077800411409878

Pasque, P., Carducci, R., Kuntz, A. K., \& Gildersleeve, R. E. (2012). Qualitative inquiry for equity in higher education: Methodological implications, negotiations and responsibilities [ASHE Higher Education Report, 37(6)]. San Francisco, CA: Jossey-Bass.

Power, M. (2004). The risk management of everything. The Journal of Risk Finance 5(3), 58-65. http:/ / dx.doi.org/10.1108/eb023001

Pusser, B., \& Marginson, S. (2013). University rankings in critical perspective. Journal of Higher Education, 84(4), 544-568. http://dx.doi.org/10.1353/jhe.2013.0022

Pusser, B., Kempner, K., Marginson, S., \& Ordorika, I. (2012). Universities and the public sphere: Knowledge creation and state building in the era of globalization (pp. 1-276). New York, NY: Routledge.

Ramírez, F. O. (2013). World society and the university as formal organizations. Sisyphus Journal of Education, 1(1), 124-153.

Rhoades, G., \& Slaughter, S. (1997). Academic capitalism, managed professionals, and supplyside higher education. Social Text, (51), 9-38. http://dx.doi.org/10.2307/466645

Rusch, E. A., \& Wilbur, C. (2007). Shaping institutional environments: The process of becoming legitimate. The Review of Higher Education, 30(3), 301-318. http:/ /dx.doi.org/10.1353/rhe.2007.0014

Sandmann, L. R., Saltmarsh, J., \& O’Meara, K. (2008). An integrated model for advancing the scholarship of engagement: Creating academic homes for the engaged scholar. Journal of Higher Education Outreach and Engagement, 12(1), 47-64.

Safón, V. (2013). What do global university rankings really measure? The search for the X factor and the X entity. Scientometrics, 1-22.

Sauder, M. \& Epseland, W. (2009). The discipline of rankings: Tight coupling and organizational change. American Sociological Review, 74(63), 63-82. http:/ / dx.doi.org/10.1177/000312240907400104 
Scott, W. R. (1991). Unpacking institutional arguments in W. Powell \& P. DiMaggio (Eds.), The new institutionalism in organizational analysis, (pp. 143-63) Chicago, IL: The University of Chicago Press.

Shin, J. C. \& Harman, G. (2009). New challenges for higher education: Global and Asia-Pacific perspectives. Asia Pacific Educational Review, 10(1) 1-13. http://dx.doi.org/10.1007/s12564009-9011-6

Shin, J.C., Toutkoushian, R.K. \& Teicher, U. (2011). University rankings: Theoretical basis, methodology, and impacts on global higher education. New York, NY: Springer. http://dx.doi.org/10.1007/97894-007-1116-7

Slaughter, S., \& Leslie, L. L. (1997). Academic capitalism: Politics, policies, and the entrepreneurial university. Baltimore, MD: The Johns Hopkins University Press.

Slaughter, S. \& Rhoades, G. (2004). Academic capitalism and the new economy: Markets, state, and higher education. Baltimore, MD: John Hopkins University Press.

Spooren, P., Brockx, B. \& Mortelmans, D. (2013). On the validity of student evaluation of teaching: The state of the art. Review of Educational Research, 83(4), 598-642. http://dx.doi.org/10.3102/0034654313496870

Spring, J. (2008). Globalization of education: An introduction. New York, NY: Routledge.

Stanley, C. (2007). When counter narratives meet master narratives in the journal editorial-review process. Educational Researcher, 36(1), 14-24. http:/ / dx.doi.org/10.3102/0013189X06298008

Stratilatis, C. (2014). University rankings and the scientification of social sciences and humanities. Ethics in Science and Environmental Politics, 13, 77-92.

Taylor, B. J., \& Morphew, C. C. (2010). An analysis of baccalaureate college mission statements. Research in Higher Education, 51, 483-503. http:/ / dx.doi.org/10.1007/s11162-010-9162-7

Times Higher Education - The World University Rankings. Retrieved from: http:/ / www.timeshighereducation.co.uk/world-university-rankings/

Toma, J. D. (2012). Institutional Strategy: Positioning For Prestige. In M. N. Bastedo (Ed.), The organization of higher education: Managing colleges for a new era (pp. 118-159), Baltimore, MD: Johns Hopkins University Press.

Torres, C. A., \& Schugurensky, D. (2002). The political economy of higher education in the era of neoliberal globalization: Latin America in comparative perspective. Higher Education, 43(4), 429-455. http://dx.doi.org/10.1023/A:1015292413037

Toutkoushian, R. K., \& Webber, K. (2011). Measuring the research performance of postsecondary institutions. In J.C. Shin, R. Toutkoushian, \& U. Teichler (Eds.), University Rankings: Theoretical basis, methodology, and impacts on global higher education (pp. 123-144), New York, NY: Springer.

Tuchman, G. (2009). Wannabe U: Inside the corporate university. Chicago, IL: University of Chicago Press. http://dx.doi.org/10.7208/chicago/9780226815282.001.0001

Ylijoki, O. (2005). Academic nostalgia: A narrative approach to academic work. Human Relations, 58(5) 555-576. http://dx.doi.org/10.1177/0018726705055963 


\section{About the Authors}

Leslie D. Gonzales

Clemson University

leslieg@clemson.edu

Leslie D. Gonzales is an Assistant Professor of Higher Education in the Educational Leadership Program at Clemson University. Gonzales's research agenda revolves around the study of legitimacy within academia and higher education, more broadly, with a specific focus on faculty evaluation and faculty careers within striving universities.

Anne-Marie Núñez

University of Texas at San Antonio

annemarie.nunez@utsa.edu

Anne-Marie Núñez is an Associate Professor of Higher Education in the Educational Leadership and Policy Studies Department at the University of Texas at San Antonio. Her research focuses on how to promote equity in postsecondary access and success, particularly for underrepresented groups.

\section{About the Guest Editor}

David Post

UNESCO GMR \& Pennsylvania State University

profdavidpost@gmail.com

David Post is Senior Policy Analyst with the Global Monitoring Report of Education For All, and is currently based at UNESCO in Paris. He also is Professor of Comparative and International Education who is currently on leave from Penn State University in the USA. He has researched and published about educational stratification, about child labor issues, as well as the politics of educational mobilization. He also investigates the impact of concurrent employment on student academic achievement. He has been a visiting professor at the Colegio de México, at the Facultad Latinoamericana de Ciencias Sociales, and at the Hong Kong University of Science and Technology. Finally, David served for ten years as editor of Comparative Education Review, where he became concerned about the commodification of scholarship and the possible responses to it by intellectuals, for example through peer-reviewed, open access publication of studies like those in this special issue. Last year, the EEPA printed the Spanish version of his commentary, "Los Rankings Académicos." http://epaa.asu.edu/ojs/article/view/1347 


\title{
SPECIAL ISSUE
The Future of Education Research Journals education policy analysis archives
}

\author{
Volume 22 Number $31 \quad$ May 5 $5^{\text {th }}, 2014$ ISSN 1068-2341
}

@)

SOMERIGHISRESERVED Readers are free to copy, display, and distribute this article, as long as the work is attributed to the author(s) and Education Policy Analysis Archives, it is distributed for noncommercial purposes only, and no alteration or transformation is made in the work. More details of this Creative Commons license are available at http://creativecommons.org/licenses/by-nc-sa/3.0/. All other uses must be approved by the author(s) or EPAA. EPAA is published by the Mary Lou Fulton Institute and Graduate School of Education at Arizona State University Articles are indexed in CIRC (Clasificación Integrada de Revistas Científicas, Spain), DIALNET (Spain), Directory of Open Access Journals, EBSCO Education Research Complete, ERIC, Education Full Text (H.W. Wilson), QUALIS A2 (Brazil), SCImago Journal Rank; SCOPUS, SOCOLAR (China).

Please contribute commentaries at http://epaa.info/wordpress/ and send errata notes to Gustavo E. Fischman fischman@asu.edu

Join EPAA's Facebook community at https://www.facebook.com/EPAAAAPE and Twitter feed@epaa_aape. 


\section{education policy analysis archives editorial board}

Editor Gustavo E. Fischman (Arizona State University)
Associate Editors: Audrey Amrein-Beardsley (Arizona State University), Rick Mintrop, (University of California, Berkeley)

Jeanne M. Powers (Arizona State University)

Jessica Allen University of Colorado, Boulder

Gary Anderson New York University

Michael W. Apple University of Wisconsin, Madison

Angela Arzubiaga Arizona State University

David C. Berliner Arizona State University

Robert Bickel Marshall University

Henry Braun Boston College

Eric Camburn University of Wisconsin, Madison

Wendy C. Chi* University of Colorado, Boulder

Casey Cobb University of Connecticut

Arnold Danzig Arizona State University

Antonia Darder University of Illinois, UrbanaChampaign

Linda Darling-Hammond Stanford University

Chad d'Entremont Strategies for Children

John Diamond Harvard University

Tara Donahue Learning Point Associates

Sherman Dorn University of South Florida

Christopher Joseph Frey Bowling Green State University

Melissa Lynn Freeman* Adams State College

Amy Garrett Dikkers University of Minnesota

Gene V Glass Arizona State University

Ronald Glass University of California, Santa Cruz

Harvey Goldstein Bristol University

Jacob P. K. Gross Indiana University

Eric M. Haas WestEd

Kimberly Joy Howard* University of Southern California

Aimee Howley Ohio University

Craig Howley Ohio University

Steve Klees University of Maryland

Jaekyung Lee SUNY Buffalo
Christopher Lubienski University of Illinois, UrbanaChampaign

Sarah Lubienski University of Illinois, UrbanaChampaign

Samuel R. Lucas University of California, Berkeley

Maria Martinez-Coslo University of Texas, Arlington

William Mathis University of Colorado, Boulder

Tristan McCowan Institute of Education, London

Heinrich Mintrop University of California, Berkeley

Michele S. Moses University of Colorado, Boulder

Julianne Moss University of Melbourne

Sharon Nichols University of Texas, San Antonio

Noga O'Connor University of Iowa

João Paraskveva University of Massachusetts, Dartmouth

Laurence Parker University of Illinois, UrbanaChampaign

Susan L. Robertson Bristol University

John Rogers University of California, Los Angeles

A. G. Rud Purdue University

Felicia C. Sanders The Pennsylvania State University

Janelle Scott University of California, Berkeley

Kimberly Scott Arizona State University

Dorothy Shipps Baruch College/CUNY

Maria Teresa Tatto Michigan State University

Larisa Warhol University of Connecticut

Cally Waite Social Science Research Council

John Weathers University of Colorado, Colorado Springs

Kevin Welner University of Colorado, Boulder

Ed Wiley University of Colorado, Boulder

Terrence G. Wiley Arizona State University

John Willinsky Stanford University

Kyo Yamashiro University of California, Los Angeles

* Members of the New Scholars Board 


\section{archivos analíticos de políticas educativas consejo editorial}

Editor: Gustavo E. Fischman (Arizona State University)

Editores. Asociados Alejandro Canales (UNAM) y Jesús Romero Morante (Universidad de Cantabria)

Armando Alcántara Santuario Instituto de Investigaciones sobre la Universidad y la Educación, UNAM México

Claudio Almonacid Universidad Metropolitana de Ciencias de la Educación, Chile

Pilar Arnaiz Sánchez Universidad de Murcia, España

Xavier Besalú Costa Universitat de Girona, España Jose Joaquin Brunner Universidad Diego Portales, Chile

Damián Canales Sánchez Instituto Nacional para la Evaluación de la Educación, México

María Caridad García Universidad Católica del Norte, Chile

Raimundo Cuesta Fernández IES Fray Luis de León, España

Marco Antonio Delgado Fuentes Universidad Iberoamericana, México

Inés Dussel FLACSO, Argentina

Rafael Feito Alonso Universidad Complutense de Madrid, España

Pedro Flores Crespo Universidad Iberoamericana, México

Verónica García Martínez Universidad Juárez Autónoma de Tabasco, México

Francisco F. García Pérez Universidad de Sevilla, España

Edna Luna Serrano Universidad Autónoma de Baja California, México

Alma Maldonado Departamento de Investigaciones Educativas, Centro de Investigación y de Estudios Avanzados, México

Alejandro Márquez Jiménez Instituto de Investigaciones sobre la Universidad y la Educación, UNAM México

José Felipe Martínez Fernández University of California Los Angeles, USA
Fanni Muñoz Pontificia Universidad Católica de Perú

Imanol Ordorika Instituto de Investigaciones Economicas - UNAM, México

Maria Cristina Parra Sandoval Universidad de Zulia, Venezuela

Miguel A. Pereyra Universidad de Granada, España

Monica Pini Universidad Nacional de San Martín, Argentina

Paula Razquin UNESCO, Francia

Ignacio Rivas Flores Universidad de Málaga, España

Daniel Schugurensky Universidad de Toronto-Ontario Institute of Studies in Education, Canadá

Orlando Pulido Chaves Universidad Pedagógica Nacional, Colombia

José Gregorio Rodríguez Universidad Nacional de Colombia

Miriam Rodríguez Vargas Universidad Autónoma de Tamaulipas, México

Mario Rueda Beltrán Instituto de Investigaciones sobre la Universidad y la Educación, UNAM México

José Luis San Fabián Maroto Universidad de Oviedo, España

Yengny Marisol Silva Laya Universidad Iberoamericana, México

Aida Terrón Bañuelos Universidad de Oviedo, España

Jurjo Torres Santomé Universidad de la Coruña, España

Antoni Verger Planells University of Amsterdam, Holanda

Mario Yapu Universidad Para la Investigación Estratégica, Bolivia 


\section{arquivos analíticos de políticas educativas conselho editorial}

Editor: Gustavo E. Fischman (Arizona State University)

Editores Associados: Rosa Maria Bueno Fisher e Luis A. Gandin

(Universidade Federal do Rio Grande do Sul)

Dalila Andrade de Oliveira Universidade Federal de Minas Gerais, Brasil

Paulo Carrano Universidade Federal Fluminense, Brasil

Alicia Maria Catalano de Bonamino Pontificia Universidade Católica-Rio, Brasil

Fabiana de Amorim Marcello Universidade Luterana do Brasil, Canoas, Brasil

Alexandre Fernandez Vaz Universidade Federal de Santa Catarina, Brasil

Gaudêncio Frigotto Universidade do Estado do Rio de Janeiro, Brasil

Alfredo M Gomes Universidade Federal de Pernambuco, Brasil

Petronilha Beatriz Gonçalves e Silva Universidade Federal de São Carlos, Brasil

Nadja Herman Pontificia Universidade Católica -Rio Grande do Sul, Brasil

José Machado Pais Instituto de Ciências Sociais da Universidade de Lisboa, Portugal

Wenceslao Machado de Oliveira Jr. Universidade Estadual de Campinas, Brasil
Jefferson Mainardes Universidade Estadual de Ponta Grossa, Brasil

Luciano Mendes de Faria Filho Universidade Federal de Minas Gerais, Brasil

Lia Raquel Moreira Oliveira Universidade do Minho, Portugal

Belmira Oliveira Bueno Universidade de São Paulo, Brasil

António Teodoro Universidade Lusófona, Portugal

Pia L. Wong California State University Sacramento, U.S.A

Sandra Regina Sales Universidade Federal Rural do Rio de Janeiro, Brasil

Elba Siqueira Sá Barreto Fundação Carlos Chagas, Brasil

Manuela Terrasêca Universidade do Porto, Portugal

Robert Verhine Universidade Federal da Bahia, Brasil

Antônio A. S. Zuin Universidade Federal de São Carlos, Brasil 